with its own entrance and assembly point. The service is intra-mural as well as extra-mural, and large numbers of school classes are received in the Schools Service Reception Room. Naturally, this part of the Service is of greatest use to the Cardiff schools. The aim of the Service is "to teach, to interest, and to inspire through objects". It is pleasing to note that this aim has been faithfully followed throughout the five years, for it is the fundamental aim of all museum. work. Although the Service was designed to help the schools, it is also interesting to recall that it has been of reciprocal service to the Museum, and many objects of value have been offered by discerning children.

\section{Self-Inhibition in Germinating Rust Uredospores}

Ir has been observed that germinating uredospores of rust fungi produce a volatile substance which, under certain conditions, inhibits the elongation of the germ tube. This phenomenon has now been investigated in greater detail by F. R. Forsyth (Canadian J. Bot., 33, 5, 363; 1955). He reports that the self-inhibition of germination of uredospores of Puccinia graminis Pers. var. tritici Erikss. and Henn. has been consistently demonstrated in Warburg flasks. Four ways of overcoming the effect of the inhibitory substance have been discovered : the use of a sufficiently large volume of water in relation to weight of spores; the placing of a silver nitrate solution in the centre well; and the introduction of acetone or ammonia vapour into the flask atmosphere. The vapour of trimethylethylene inhibits germination of the uredospores in the same way that the natural inhibitor does, and the same means can be used for counteracting its effects. The similarity of the absorption spectra of the inhibitor and of trimothylethylene in acetone solutions indicates that trimethylethylene is the natural inhibitor. Cyclohexene has formative and inhibitory effects on the germ tubes, and these effects can be overcome by vapour of acetone.

\section{Physiological Genetics of the Garden Pea}

In grafting experiments using early and late varieties of Pisum, D. M. Paton and H. N. Barber (Austral. J. Biol. Sci., 8, 2, 231; 1955) have found that when genetically early scions of $P$. sativum var. Massey are grafted on to genetically late stocks of var. Telephone, flowering on a higher node results. In reciprocal grafts, the scions of the late varietiy flower at an earlier (lower) node. Control grafting, that is, scions to stocks of the same variety, has no effect on Massey scions but leads to flowering at a lower node in the Telephone scions. Removal of cotyledons as soon as possible after germination (3-7 days) has no effect on Massey but leads to earlier flowering in Telephone. The authors consider that these results are best explained on the assumption that the genetically later variety produces a flower inhibitor (or delaying) substance which can pass a graft union and alter the flowering behaviour of genetically early scions.

\section{Meteorological Observations of Solar Radiation during an Eclipse}

A PAPER by R. Dogniaux on "Observations of the Solar Radiation during the Eclipse of the Sun on June 30, 1954" (Pub. No. 13, Sér. B, Institut Royal Météorologique de Belgique, Bruxelles) describes the results of determining the radiations of the sun during the greatest phase $(0 \cdot 774)$, at Uccle, of the eclipse of
June 30, 1954. Six figures show the results under various conditions, and from them the reductions in brightness during the course of the eclipse were calculated. The direct solar radiation was reduced to 14 per cent at the instant of greatest phase, diffused radiation to 35 per cent, and the total brightness to 25 per cent. With the aid of photoelectric cells, similar observations of the radiations to which the human eye is sensible were made, and it was found that these were reduced to 20,28 and 12 per cent for the total, diffused and direct radiation on a horizontal surface, respectively. One of the figures shows the temperature reductions during the eclipse under a ventilated shelter on a platform, at a distance of $1 \mathrm{~cm}$. under bare ground and also at a distance of $1 \mathrm{~cm}$. under grass. Although it is certain that the effect of the eclipse is shown in the changes of temperature, and in particular under the bare earth, as revealed by the first graph of this figure, it is impossible to decide what percentage of this was actually due to the eclipse. The variation of cloudiness was such that its effect was very pronounced; nevertheless, the results show that the propagation of the heat differed for air, bare soil, and soil protected by grass.

\section{Thirtieth International Congress of Americanists : Proceedings}

THe thirtieth International Congress of American. ists met at Cambridge in August 1952, under the presidency of Mr. J. Eric S. Thompson, the distinguished Maya epigraphist, and the proceedings have now been published (pp. 250. London: Royal Anthropological Institute). Americanist Congresses, which in the words of their statutes have for their object "the historic and scientific study of the two Americas and their inhabitants", normally take place every two years and alternate between the old and the New World. The thirtieth Congress was the first to meet in England since 1912, when the eighteenth Congress met in London. The terms of reference of these Congresses admit a wide range of subjects, and only a few of the thirty-seven published papers can be mentioned here. By far the most interesting communication is an account of the recent explorations at the great Maya site of Palenque by Señor Alberto Ruz, in which he describes the discovery of an important burial chamber beneath the Temple of the Inscriptions, an outstanding instance of the rare practice of burying notable people beneath an American temple-pyramid. There are several other papcrs in the Maya field, including one on the Maya character by Mr. Thompson. Other interesting archæological papers are on the excavation of a shell mound, or sambaquí, in Brazil, by Prof. L. de Castro Faría, and on transport in Peru, by Dr. Paul Kosok. In linguistics there are two papers on Alaskan languages by Prof. L. L. Hammerich; in ethnology a study of the peyote cult by Dr. Ruth Underhill ; and on the historical side a note by Dr. M. Ballesteros-Gaibrois on a manuscript of Fray Martín de Murúa, "Historia General del Perú", in the possession of the Duke of Wellington. Mr. Thor Heyerdahl has three papers relating to his theorics of the population of Polynesia by voyagers from South America, which aroused some popular interest at the time of the Congress, although he had as 'rough' a time in the discussions as ever he had on the Kon Tiki raft. A feature of the Congress was a notable loan exhibition of nearly all the ancient Mexican manuscripts in Great Britain, to which was 